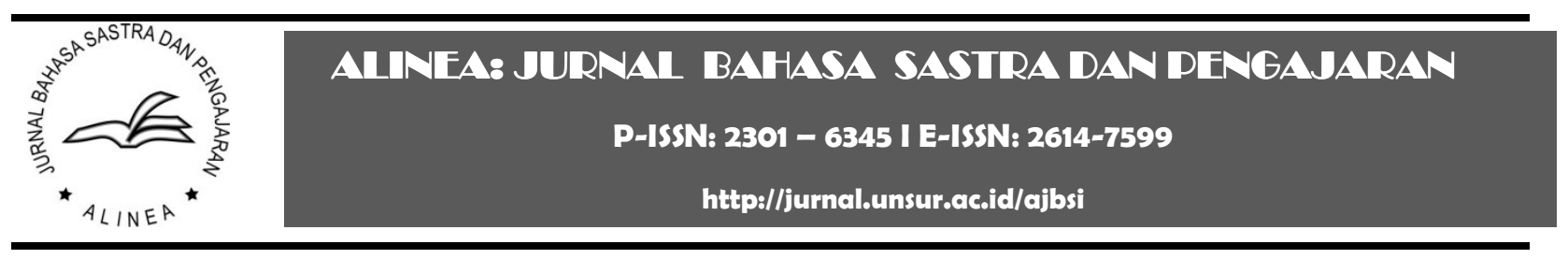

\title{
MENINGKATKAN KREATIVITAS MENULIS TEKS ANEKDOT DENGAN MENGGUNAKAN MODEL PROBLEM BASED LEARNING
}

\author{
Neni Mariam Apriani \\ Madrasah Aliyah Negeri 2 Cianjur
}

Riwayat artikel:

Dikirim: 16 Oktober 2018

Direvisi: 17 April 2019

Diterima: 7 Oktober 2019

Diterbitkan: 30 Oktober 2019

Katakunci:

anekdot

Problem Base Learning

Alamat surat

mariam23@gmail.com

\begin{abstract}
Abstrak:
Tulisan ini mendeskripsikan peningkatan efektivitas pembelajaran menulis teks anekdot dengan menggunakan model Problem Based Learning (PBL) pada siswa kelas X MAN 2 Cianjur. Metode penelitian yang digunakan yaitu Penelitian Tindakan Kelas dengan dua siklus, setiap siklus dua kali pertemuan. Data diperoleh dengan angket, observasi, dan tes. Hasil penelitian menunjukkan bahwa penggunaan model PBL mampu meningkatkan kualitas proses pembelajaran. Selain itu, model PBL dapat meningkatkan kreativitas menulis teks anekdot, skor rata-rata kreativitas menulis teks anekdot saat pratindakan $67 \%$ setelah diberi tindakan (siklus I) meningkat $7 \%$ menjadi $74 \%$ dan siklus II meningkat lagi sebesar 6\% menjadi 80\%. Oleh karena itu, dapat disimpulkan bahwa penggunaan model PBL dapat meningkatkan keterampilan menulis teks anekdot siswa kelas X IPS 4 MAN 2 Cianjur
\end{abstract}

\begin{abstract}
:
This paper describes an increase in the effectiveness of learning to write anecdotal texts by using Problem Based Learning (PBL) model. The research method used was Classroom Action Research with two cycles, each cycle consisted of two meetings. Data obtained from questionnaire, observation, and test. The results show that the use of PBL model was able to improve the quality of the learning process. In addition, PBL models could increase the creativity of writing anecdotal texts. This can be seen from the students' average score of writing anecdotal text in pre-action was $67 \%$, after an action was implemented in the first cycle it increased $7 \%$ to $74 \%$ and after the second cycle the average score of writing an anecdotal text on Grade 2 students at MAN 2 Cianjur increased $6 \%$ to $80 \%$. Therefore, it can be concluded that the use of PBL model can improve anecdotal text writing skills of students of class X IPS 4 MAN 2

Cianjur.
\end{abstract}

\section{PENDAHULUAN}

Keterampilan menulis tidak mungkin dikuasai hanya melalui teori, tetapi dilaksanakan melalui latihan dan praktik yang teratur sehingga menghasilkan tulisan yang tersusun baik. Dalam keterampilan menulis, siswa dituntut untuk menguasai kosakata, pengetahuan, dan pengalaman agar dapat menyampaikan gagasan-gagasan dengan baik kepada pembaca.

Salah satu faktor yang diperlukan oleh guru dalam pelaksanaan pembelajaran bahasa
Indonesia yaitu model pembelajaran. Di dalam Kegiatan belajar mengajar dibutuhkan suatu model pembelajaran yang memenuhi, agar siswa tidak merasa bosan dengan materi yang diajarkan oleh guru.

Penelitian ini melanjutkan penelitian yang sebelumnya, bukan hanya pemahaman siswa terhadap struktur pembangun tetapi pemahaman itu akan diimplementasikan ke dalam sebuah produk yang berbentuk teks anekdot dengan memperhatikan kebahasaan dalam menulis teks anekdot yang dihasilkan oleh siswa secara kolaboratif maupun individual. 
Permasalahan tersebut perlu diperhatikan karena kemampuan menulis teks anekdot sangat berperan dalam pembelajaran Bahasa dan Sastra Indonesia. Upaya untuk membantu siswa mengatasi rendahnya keterampilan menulis teks anekdot, salah satunya dapat ditempuh dengan cara meningkatkan penggunaan model pembelajaran, karena kurikulum 2013 menuntut siswa untuk lebih berperan aktif dalam pembelajaran. Oleh karena itu, untuk menciptakan pembelajaran yang efektif, guru dituntut untuk lebih kreatif dan inovatif.

Dalam upaya untuk dapat meningkatkan kreativitas menulis digunakan model Pembelajaran Berbasis Masalah (Problem Based Learning) selanjutnya akan digunakan istilah PBM. Dengan harapan penggunaan PBM dapat meningkatkan hasil pembelajaran, terutama dalam meningkatkan kreativitas pada saat menulis, karena menurut Colliver dkk. PBL dapat meningkatkan basis pengetahuan dan kinerja klinis (Colliver). Selanjutnya, Taconis dkk. menjelaskan bahwa "Problemsolving strategies play a central role in education. Many tasks performed in professional and daily life require such strategies, which we define as planned sequences of activities leading to a goal, the solution of the problem (Taconis et al.).

Kemudian menurut penelitian Erna Marlina PBM yang dikombinasikan dengan pengguna media audio visual ternyata lebih efektif dibandingkan dengan tanpa menggunakan PBM (Marlina). karena pembelajaran berbasis masalah merupakan sebuah model pembelajaran yang menyajikan masalah kontekstual sehingga merangsang siswa untuk belajar. Model pembelajaran berdasarkan masalah adalah model pembelajaran yang menggunakan masalah sebagai langkah awal untuk mendapatkan pengetahuan baru.

Model pembelajaran berbasis masalah ini melibatkan siswa dalam proses pembelajaran yang aktif dan kolaboratif. Selain itu, model berbasis masalah ini, berpusat kepada siswa dengan mengembangkan kemampuan pemecahan masalah dan kemampuan belajar mandiri.

Tulisan ini akan membahas cara meningkatkan kreativitas menulis teks anekdot pada siswa dengan menggunakan model pembelajaran berbasis masalah. Penelitian dilakukan di X MAN 2 Cianjur karena sesuai dengan hasil wawancara awal, model pembelajaran berbasis masalah belum diterapkan dalam pembelajaran menulis teks anekdot di kelas $\mathrm{X}$ yang sesuai dengan pengembangan dari kurikulum 2013.

Beberapa hal yang akan dibahas antara lain bagaimana kreativitas awal menulis teks anekdot siswa dan bagaimanan peningkatan kreativitas menulis teks anekdot dengan model Problem Based Learning pada siswa kelas X MAN 2 Cianjur.

Perlu dikemukakan apa yang dijelaskan Dalman. Ia mengungkapkan bahwa menulis merupakan sebuah proses kreatif menuangkan gagasan dalam bentuk bahasa tulisan dalam tujuan, misalnya memberitahu, meyakinkan, dan menghibur. Hasil dari proses ini biasanya disebut dengan istilah karangan atau tulisan (Dalman).

Pendapat tersebut diambil sebagai teori dalam konsep penelitian ini yaitu tentang kreativitas menulis yang difokuskan kedalam menulis teks anekdot, karena menulis merupakan kegiatan menggambarkan atau memaparkan proses kreatif dalam menuangkan ide atau gagasan ke dalam bentuk tulisan yang disusun secara utuh untuk memperoleh tujuan tertentu.

Di dalam kegiatan belajar diperlukan proses berpikir kreatif. Proses berpikir kreatif tersebut diperlukan untuk menyelesaikan atau menjawab segala masalah dalam kegiatan belajar-mengajar. Rogers mendefiniskan kreativitas sebagai proses munculnya hasil-hasil baru ke dalam tindakan. Hasil-hasil baru itu muncul dari sifat-sifat individu yang unik yang berinteraksi dengan individu lain, pengalaman, maupun keadaan hidupnya (Munandar). 
Selanjutnya, perlu juga dikemukakan tentang teks anekdot. Teks anekdot menurut merupakan bagian dari teks yang berupa narasi yang independen serta cerita yang berdiri sendiri (Keraf). Kemendikbud menyatakan bahwa anekdot ialah cerita singkat yang menarik karena lucu dan mengesankan, biasanya mengenai orang penting atau terkenal dan berdasarkan kejadian yang sebenarnya. Anekdot dapat berupa cerita rekaan yang tidak perlu didasarkan pada kenyataan yang terjadi di masyarakat (Kemendikbud).

Menurut Sabar (2014) bahwa teks anekdot pada umumnya terdiri dari 5 bagian, antara lain 1) Abstrak, 2) Orientasi, 3) Krisis, 4) Reaksi, dan 5) Koda (Sabar). Selanjutnya dijelaskan bahwa kaidah kebahasaan dalam teks anekdot yaitu: 1) menggunakan katakata yang menunjukkan masa lampau, 2) menggunakan pertanyaan retoris atau pertanyaan yang tidak perlu dijawab, 3) menggunakan konjungsi (terutama kata sambung waktu yang menyatakan urutan peristiwa), 4) menggunakan kata kerja, 5) menggunakan kalimat perintah, 6) mengandung unsur lucu, 7) menyindir dengan menggunakan plesetan atau perumpamaan, dan 8) partisipan.

Di dalam penelitian, model pembelajaran yang digunakan yaitu model pembelajaran berbasis masalah atau problem based learning dengan penggunaan singkat yang berupa PBL. Model PBL dilaksanakan untuk mengembangkan keterampilan menyelesaikan masalah dan berfikir kritis serta sekaligus membangun pengetahuan baru.

Siswa secara kritis mengidentifikasi informasi dan startegi yang relevan serta melakukan penyelidikan untuk menyelesaikan masalah tersebut (Rusman).

Tujuan utama model PBL yaitu dirancang untuk dapat merangsang dan melibatkan pembelajaran dalam pola pemecahan masalah (Faturrahman).

\section{METODE}

Metode penelitian yang digunakan adalah penelitian tindakan kelas. Penelitian difokuskan pada kegiatan siswa dan guru selama pembelajaran untuk meningkatkan aktivitas dan kemampuan kreativitas siswa terhadap menulis teks anekdot. Kegiatan pembelajaran direfleksikan untuk menentukan tindakan selanjutnya sehingga berbagai kekurangan atau kelemahan pembelajaran sebelumnya dapat diatasi dan diperbaiki.

Subjek dalam penelitian yaitu siswa kelas $\mathrm{X}$ MAN 2 Cianjur dengan jumlah siswa 41 orang siswa. Penelitian ini dilakukan dua siklus yang masing-masing siklus dilakukan selama dua kali pertemuan. Sebelum melaksanakan tindakan, peneliti melakukan kegiatan pratindakan untuk memperoleh kretaivitas menulis teks anekdot siswa kelas X IPS 4 MAN 2 Cianjur.

Instrumen yang digunakan dalam penelitian yaitu lembar tes (tes pratindakan dan tes setelah tindakan), lembar observasi dan lembar angket (angket pratindakan), (angket sebelum tindakan) dan pascatindakan (setelah tindakan). Kriteria keberhasilan penelitian dapat dilihat dari peningkatan proses kegiatan dan produk yang dihasilkan oleh siswa. Proses kegiatan dinilai dari hasil observasi dan angket, sedangkan produk dilihat dari peningkatan kreativitas siswa pada setiap siklus yang mengalami peningkatan $\geq$ 75. Aspek yang dinilai dalam kegiatan menulis yaitu aspek isi, struktur, kosakata, kalimat, dan mekanik.

\section{HASIL DAN PEMBAHASAN}

Sebelum melaksanakan suatu tindakan, penelitian ini terlebih dahulu melakukan kegiatan prasiklus atau pratindakan. Kegiatan ini bertujuan untuk mengetahui minat dan keterampilan awal siswa dalam menulis teks anekdot. Kegiatan ini dilaksanakan di MAN 2 Cianjur khususnya kelas X IPS 4 pada hari Rabu, 26 April 2017. Untuk memperoleh data tersebut digunakan tes awal menulis teks anekdot dan angket awal.

Nilai rata-rata dihitung dari jumlah setiap aspek menulis teks anekdot seluruh siswa yaitu 
64, sedangkan nilai KKM yang dijadikan patokan yaitu 75. Siswa yang memperoleh nilai dibawah KKM berjumlah 33 siswa.

Angket digunakan untuk menjaring informasi awal pada kegiatan prasiklus. Berdasarkan angket diketahui bahwa minat siswa kelas X IPS 4 MAN 2 Cianjur terhadap pembelajaran Bahasa Indonesia khususnya menulis anekdot masih rendah, dibuktikan dengan persentasi sebanyak $82 \%$ siswa merasa kesulitan menuangkan ide dalam menulis teks anekdot. Akan tetapi, mereka sadar bahwa pembelajaran menulis anekdot memerlukan banyak latihan dan siswa berkeinginan dapat menulis anekdot dengan baik dibuktikan dengan $90 \%$ siswa yang berminat.

Dalam melaksanakan penelitian, peneliti bekerja sama dengan guru bahasa Indonesia, yaitu Dra. Ai Hasmawati sebagai observer I dan teman sejawat yaitu Siti Nursansan sebagai observer II. Kegiatan pembelajaran dari pratindakan sampai siklus kedua dilaksanakan oleh peneliti.

\section{Siklus I}

Perencanaan penelitian tindakan kelas pada siklus I dirancang oleh peneliti dan dilaksanakan selama dua kali pertemuan dengan alokasi waktu $4 \times 40$ menit.

Perencanaan pada siklus I ini yaitu dengan mempersiapkan skenario pembelajaran (RPP), pedoman penilaian, dan penunjang dalam melakukan penelitian.

Pertemuan pertama siklus I dilaksanakan pada hari Jumat, 28 April 2017 pukul 08.20 09.40 WIB, pembelajaran dilaksanakan di ruang kelas. Tujuan pembelajaran yaitu agar siswa mampu memahami struktur teks anekdot serta mampu membedakan teks humor dengan teks anekdot.

Pertemuan kedua dilaksanakan pada hari Rabu, 3 Mei 2017 pukul 10.00-11.20 WIB. Peneliti mencoba memberikan gambaran berbagai masalah yang ada di sekitar dengan tema sosial. Setelah memberikan gambaran tentang berbagai masalah yang ada di sekitar, peneliti memberikan tindakantindakan kepada siswa seperti mengorganisasi siswa pada masalah, mengorganisasi siswa untuk belajar, membimbing siswa dalam belajar, memberikan pertanyaan tentang kesulitan yang dihadapi, dan mengevaluasi hasil pembelajaran bersama siswa.

Peneliti bersama para observer melakukan pengamatan dan evaluasi terhadap jalannya perlakuan tindakan. Subjek yang di observasi yaitu aktivitas siswa dalam mengikuti kegiatan pembelajaran teks anekdot dan aktivitas peneliti sebagai pendidik dalam melaksanakan perlakuan yang menggunakan model PBL.

Keberhasilan proses siklus I dilaksanakan dengan dua kali pertemuan. Aktivitas siswa pada awal tindakan pembelajaran cenderung pasif. Peneliti pun lebih meningkatkan rasa ingin tahu siswa dengan menumbuhkan sikap keberaniannya untuk bertanya baik kepada peneliti maupun kepada siswa yang lain. Keseluruhan skor yang didapat dari siklus pertama pertemuan pertama yaitu 3,1 poin dengan presentasi $78 \%$.

Keberhasilan produk dapat dilihat dari peningkatan hasil tes menulis teks anekdot setelah diberi tindakan pada siklus I dibandingkan dengan hasil yang diperoleh pada tes sebelum dilakukan tindakan (pratindakan). Peningkatan kreativitas menulis teks anekdot pada siswa kelas X IPS 4 pada siklus I dengan menggunakan model PBL terjadi sebesar 10 poin dari pratindakan sebesar 64 poin menjadi 74 poin di siklus I. Tetapi peningkatan tersebut belum memenuhi standar kelulusan atau KKM yang telah ditentukan yaitu sebesar 75. Maka dari itu perlu diadakan siklus II untuk melakukan tindakan perbaikan.

Peneliti bersama para observer berdiskusi untuk mengatasi beberapa permasalahan yang timbul pada siklus I yaitu penggunaan kosakata dan penulisan kalimat langsung dan tak langsung yang belum tepat. 


\section{Siklus II}

Siklus II, tindakan yang diberikan hampir sama dengan tindakan pada siklus I tetapi terdapat beberapa penambahan tindakan sebagai perbaikan tindakan siklus I. Perencanaan dan persiapan yang dilakukan dalam siklus II yaitu dengan menyiapkan lembar kerangka menulis teks anekdot dan menyiapkan video yang berjudul "Pena Tanpa Jejak".

Kegiatan pembelajaran atau pelaksanaan tindakan dilaksanakan selama dua kali pertemuan. Pada siklus II ini kegiatan pembelajaran menggunakan rekaman video yang berjudul "Pena Tanpa Jejak". Diharapkan dengan cara memperlihatkan video tentang suatu peristiwa yang sering terjadi dikalangan anak remaja khususnya SMA sehingga siswa dapat lebih kreatif menulis teks anekdot yang original.

Pertemuan pertama siklus II ini dilaksanakan pada hari Jumat, 05 Mei 2017. Kegiatan pembelajaran jam pertama dimulai pukul 08.20 - 09.00 WIB jam kedua dimulai pukul 09.30 $10.10 \mathrm{WIB}$.

Pada pertemuan kedua sikuls II, pelaksanaan tindakan dalam penelitian ini berlangsung Jumat, 12 Mei 2017. Peneliti didampingi oleh para observer untuk melaksanakan kegiatan tindakan pembelajaran.

Observasi dilakukan selama proses pembelajaran berlangsung. Pelaksanaan pemantauan meliputi dampak tindakan terhadap proses pembelajaran dalam hal keberhasilan proses yang dinilai oleh observer dan terhadap hasil pembelajaran keberhasilan produk yang dinilai oleh peneliti.

Dengan perolehan skor $93 \%$ yang dapat dikategorikan sangat baik, siswa sangat antusias mengikuti pembelajaran yang telah berlangsung, hal tersebut dapat dilihat dari aspek kerjasama yang meningkat, perhatian siswa terhadap apa yang dterangkan oleh guru, aktif dalam bertanya, berpartisipasi dalam kelompok yang sangat baik dan tepat dalam mengerjakan tugas yang diberikan oleh peneliti.

Pada siklus II ini penerapan model PBL dengan media pembelajaran yang lebih variatif mengalami peningkatan pada keberhasilan produk. Dibandingkan dengan siklus I, nilai rata-rata keterampilan menulis anekdot pada siklus II mengalami peningkatan sebanyak 6 poin yaitu dari skor rata-rata 74 pada siklus I menjadi 80 pada siklus II.

Peneliti dan para observer melakukan diskusi untuk menentukan keberhasilan tindakan yang telah dilakukan. Hasil diskusi peneliti dan para observer tentang keberhasilan tindakan tersebut yaitu tindakan-tindakan yang diberikan pada siklus II telah memberikan peningkatan keterampilan menulis teks anekdot yang baik. Peningkatan itu dapat dilihat dari segi proses pembelajaran menulis anekdot dengan model pembelajaran PBL maupun dari segi produk, yaitu nilai rata-rata menulis teks anekdot yang mengalami peningkatan.

Berdasarkan angket pascatindakan dapat disimpulkan bahwa peningkatan keterampilan menulis teks anekdot dengan model PBL telah berhasil. Model PBL dinilai berhasil meningkatkan minat siswa serta kemampuan siswa dalam pembelajaran menulis teks anekdot.

Pembahasan hasil penelitian ini meliputi (1) informasi awal dan pengalaman siswa dalam menulis teks anekdot serta tes awal menulis teks anekdot (pratindakan) dan (2) upaya meningkatkan kreativitas menulis teks anekdot dengan model Problem Based Learning pada siswa kelas X MAN 2 Cianjur.

Berdasarkan angket informasi awal yang dilakukan pada kegiatan prasiklus, diketahui bahwa tingkat minat siswa kelas X IPS 4 MAN 2 Cianjur terhadap pembelajaran Bahasa Indonesia khususnya menulis teks anekdot masih rendah. Banyak hal yang mempengaruhi kurangnya minat siswa terhadap pembelajaran menulis teks anekdot.

Praktik menulis dirasa masih kurang, sehingga siswa pun kurang terampil dalam 
praktik menulis teks anekdot. Selain itu, kurangnya keterampilan guru dalam menentukan model pembelajaran dalam kegiatan menulis teks anekdot. Sarana pembelajaran seperti ketersediaan buku dirasa kurang, karena menurut pernyataan siswa bahwa buku yang dipakai hanya Lembar Kerja Siswa (LKS) dan buku paket yang digunakan masih menggunakan kurikulum 2006 (KTSP), sedangkan teks anekdot merupakan teks yang baru ditingkat SMA/ MA khususnya kelas X. Dengan masalah tersebut, pemahaman tentang teks anekdot pun kurang, karena masih banyak siswa yang beranggapan bahwa teks anekdot yaitu teks humor yang tidak terdapat unsur kritik di dalamnya.

Hasil menulis siswa kelas X IPS 4 MAN 2 Cianjur masih dirasa kurang, karena setelah diolah hasil menulis teks anekdot pada kegiatan prasiklus (tes awal) skor rata-rata yang diperoleh hanya 67 poin, hal ini masih kurang mencapai standar ketuntasan sekolah yaitu $\geq 75$. Dari informasi awal keterampilan menulis dan hasil tes awal yang diperoleh tersebut, maka perlu dilakukan pembenahan dan inovasi yang kreatif dalam pembelajaran menulis teks anekdot.

Pelaksanaan pembelajaran menulis anekdot menggunakan PBL yang dilaksanakan dalam dua siklus, kegiatan menulis teks anekdot ini dilaksanakan secara bertahap.

Berdasarkan pengamatan yang telah dilakukan pada siklus I dan siklus II, semua aspek dalam pembelajaran menulis anekdot telah mengalami peningkatan. Aktivitas siswa dan peneliti sudah meningkat ke arah suasana belajar yang efektif. Dari segi hasil pembelajaran, peningkatan dapat dilihat dari nilai rata-rata hasil praktik menulis teks anekdot siswa yang meningkat dibandingkan dengan tes awal menulis teks anekdot sebelum dikenai tindakan pada siklus I.

Pada siklus II dilakukan beberapa perbaikan mengenai hal-hal yang masih dirasa belum meningkat pada siklus I. Aktivitas pada siklus II banyak mengalami peningkatan. Dari segi hasil, pada siklus II telah mengalami peningkatan yang cukup signifikan dari hasil menulis sebelumnya.

Pada siklus I sampai pada siklus II telah mengalami peningkatan. Kekurangan yang masih ditemukan dalam siklus I mengenai kurangnya perhatian dan keaktifan siswa berhasil diatasi pada siklus II sehingga proses pembelajaran telah berjalan sesuai dengan tujuan tindakan. Secara proses, tindakan dalam penelitian ini dianggap berhasil apabila dalam pelaksanaan tindakan siswa memiliki perhatian terhadap pembelajaran, semangat belajar, dan aktif bertanya jawab.

Peningkatan kualitas produk dalam aktivitas belajar siswa berdampak positif pada tercapainya peningkatan kualitas hasil pembelajaran. Dalam menulis teks anekdot terdapat lima aspek yang perlu diperhatikan yaitu, isi, struktur, kosakata, kalimat dan mekanik.

\section{Aspek Isi}

Pada siklus II telah mengalami peningkatan 4 poin dibandingkan skor rata-rata pada tes pratindakan yaitu 19 poin menjadi 22 pada siklus II. Sedangkan dengan siklus I peningkatannya 1 poin yaitu 22 dari siklus I menjadi 23 dari siklus II.

\section{Aspek Struktur}

Setelah diberi tindakan pada siklus II diperoleh skor rata-rata 17 . Hal ini berarti pada siklus II telah mengalami peningkatan 1 poin dari skor awal menulis teks anekdot pada siklus I yaitu 16 poin.

\section{Aspek Kosakata}

Skor rata-rata yang diperoleh pada aspek kosakata sebelum diberi tindakan sebesar 15 poin. Setelah diberi tindakan pada siklus I diperoleh skor rata-rata 16. Pada siklus II diberi diperoleh skor 17 dari skor maksimal 20 poin. 


\section{Aspek Kalimat}

Dari 41 siswa sebelum diberi tindakan diperoleh skor rata-rata sebesar 15 . Setelah diberi tindakan pada siklus I diperoleh skor rata-rata 16 , meningkat 1 poin. Kemudian setelah diberi tindakan pada siklus II diperoleh skor rata-rata 17 dari skor maksimal 20 poin.

\section{Aspek Mekanik}

Sebelum diberi tindakan, skor rata-rata 8. Setelah diberi tindakan pada siklus I diperoleh skor rata-rata 8 . Skor rata-rata pada siklus II diperoleh skor rata-rata 9. Hal ini berarti telah mengalami peningkatan 1 poin dari selisih antara siklus II dan siklus 1. Skor maksimal aspek ini adalah 10 poin.

\section{Keterampilan Menulis Teks Anekdot de- ngan PBL}

Penggunaan model PBL dalam pembelajaran menulis teks anekdot telah berhasil meningkatkan keterampilan siswa dalam menulis teks anekdot. Peningkatan keterampilan menulis teks anekdot siswa terjadi dari pemberian tindakan pada siklus I sampai tindakan pada siklus II. Peningkatan yang dicapai terjadi pada setiap aspek dan kriteria dalam penulisan teks anekdot.

\section{Aspek Isi}

Aspek isi mempunyai empat kriteria, yaitu kesesuaian cerita dengan tema, kreativitas dalam menggembangkan cerita (struktur teks anekdot), ketuntasan cerita, dan kesinambungan. Aspek isi pada setipa siklus mengalami perubahan.

Sebelum dilakukan tindakan (pratindakan), perolehan nilai ratarata aspek isi yaitu 19, setelah dilakukan tindakan pada siklus I mengalami peningkatan yaitu 3 poin menjadi 22, sedangkan pada siklus II mengalami peningkatan 1 poin menjadi 23.

\section{Aspek Struktur}

Aspek struktur berkaitan dengan struktur teks anekdot yang mencakup lima hal, yaitu abstraksi, orientasi, krisis, reaksi, dan koda. Terdapat peningkatan di dalam aspek struktur menulis teks anekdot. Dapat dilihat pada hasil menulis teks anekdot pada kegiatan prasiklus hanya memperoleh nilai rata-rata 14 , setelah dilakukan tindakan pada siklus I terdapat peningkatan menjadi 16, sedangkan pada siklus II terjadi peningkatan 1 poin menjadi 17.

\section{Aspek Kosakata}

Aspek ini mengacu pada penggunaan potensi kata atau pemilihan kata. Aspek kosakata menulis teks anekdot mengalami peningkatan 1 poin pada setiap siklus. Hal ini dapat dilihat pada peningkatan yang ada pada siklus 1 yaitu pada prasiklus aspe kosakata mencapai 15 meningkat di siklus I menjadi 16 dan mengalami peningatan pada siklus II menjadi 17 poin.

\section{Aspek Kalimat}

Aspek kalimat ini mengacu pada struktur kalimat dan keefektifan kalimat. Berikut hasil dari pratindakan sampai siklus II. Aspek kalimat menulis teks anekdot mengalami peningkatan sama dengan aspek kosakata 1 poin pada setiap siklus. Hal ini dapat dilihat pada peningkatan yang ada pada siklus 1 yaitu pada prasiklus aspek kalimat mencapai 15 poin meningkat di siklus I menjadi 16 dan mengalami peningatan pada siklus II menjadi 17 poin.

\section{Aspek Mekanik}

Aspek mekanik mengacu pada penulisan kata, penempatan huruf kapital, dan pemakaian tanda baca. aspek mekanik hanya mengalami peningkatan pada siklus II saja yaitu dengan peningkatan 1 poin yaitu pada kegiatan pratindakan dan siklus I pemerolehan sor hanya 8 poin dan menjadi 9 poin pada siklus II. Berdasarkan pemaparan berbagai aspek tersebut, dapat diketahui bahwa terdapat peningkatan pada setiap aspek. 


\section{PENUTUP}

Berdasarkan pembahasan dalam penelitian tindakan kelas di kelas X IPS 4 MAN 2 Cianjur, dapat disimpulkan bahwa sebelum dilakukan tindakan, pengetahuan dan kreativitas menulis teks anekdot siswa kelas $\mathrm{X}$ IPS 4 masih dalam kriteria rendah.

Adanya peningkatan dan perubahan positif pada aspek situasi belajar, perhatian, keaktifan, serta proses belajar mengajar menjadikan pembelajaran menulis teks anekdot lebih menarik, menyenangkan, dan tidak membosankan. Hal ini dilakukan dengan cara peneliti memfokuskan pembelajaran kepada siswa untuk mencari informasi tentang teks anekdot dan permasalahan yang sering dialami atau dilihat di sekitar mereka.

Pembelajaran dengan model PBL dapat meningkatkan hasil kreativitas menulis teks anekdot. Hal ini terlihat dari skor rata-rata menulis teks anekdot sebelum diberi tindakan adalah 67 , setelah diberi tindakan pada akhir siklus I skor rata-rata menjadi 74. Skor ratarata menulis teks anekdot pada akhir siklus II yaitu 80. Hal tersebut menunjukkan adanya peningkatan sebesar 13 poin.

Berdasarkan hal tersebut peneliti merekomendasikan model PBL agar dijadikan model pembelajaran dalam kegiatan pembelajaran bahasa Indonesia agar pembelajaran lebih menarik, inovatif, menyenangkan, dan tidak membosankan.

Penelitianhanya dilakukan pada siswa kelas X IPS 4 MAN 2 Cianjur sedangkan pembelajaran bahasa Indonesia untuk keterampilan menulis teks anekdot diajarkan pada Sekolah Menengah Atas, bahkan permasalahan yang ditemukan pasti berbeda. Oleh karena itu, disarankan untuk penelitian selanjutnya dilakukan pada jenjang SMA agar kemampuan siswa menjadi meningkat khususnya dalam keterampilan menulis. Selain itu, penelitian ini hanya mengambil pokok bahasan menulis teks anekdot, disarankan agar mencoba pada materi yang lain.

\section{DAFTAR PUSTAKA}

Colliver, Jerry A. "Effectiveness of Problem-Based Learning Curricula: Research and Theory." Academic Medicine, 2000, doi:10.1097/00001888-200003000-00017.

Dalman. Keterampilan Menulis. PT Taja Grafindo Persada, 2014.

Faturrahman. Model-Model Pembelajaran Inovatif Alternatif Desain Pembelajaran Yang Menyenangkan. Arruzz Media, 2015.

Kemendikbud. Buku Siswa Bahasa Indonesia Ekspresi Diri dan Akademik. Pusat Kurikulum dan Perbukuan, Balitbang Kemdikbud, 2014.

Keraf, Gorys. Argumen Dan Narasi. PT Gramedia, 2001.

Marlina, Erna. "Comparison of the Problem Based Learning and Inquiry Model with the Visual Media in Improving the Ability to Write Short Stories." Alinea: Jurnal Bahasa, Sastra, dan Pengajaran, vol. 8, no. 1, 2019, pp. 7-17, doi:10.35194/alinea.v2i1.501.

Munandar, Utami. Anak Unggul Berotak Prima. PT Gramedia Pustaka Utama, 2002.

Rusman. Model-Model Pembelajaran. Raja Grafindo Persada, 2008.

Sabar, Iman. Pengertian Anekdot, Ciri-Ciri, Jenis, Struktur, dan Contoh. 2014, https://sabariman152.wordpress.com/2014/10/16/teksanekdot-ciri-ciri-jenisstruktur-dancontohnya.

Taconis, R., et al. "Teaching Science Problem Solving: An Overview of Experimental Work." 
122 Alinea, Jurnal Bahasa, Sastra, dan Pengajaran

Volume 8, (2) Oktober 2019, hal. 114-122

Journal of Research in Science Teaching, vol. 38, no. 4, 2001, pp. 442-68, doi:10.1002/tea.1013. 